\title{
ASSESSMENT OF LOCAL CHROMITE SAND AS 'GREEN' REFRACTORY RAW MATERIALS FOR SAND CASTING APPLICATIONS IN A POST-PANDEMIC WORLD
}

\author{
J.K. Kabasele ${ }^{1 *} \&$ K.D. Nyembwe ${ }^{1}$
}

\section{ARTICLE INFO}

\section{Article details \\ Presented at the $32^{\text {nd }}$ annual conference of the Southern African Institute for Industrial Engineering (SAIIE), held from 4-6 October 2021 in Muldersdrift, South Africa. \\ Available online \\ 29 Nov 2021 \\ Contact details \\ Corresponding author \\ kabasele.jonathan@yahoo.fr \\ Author affiliations \\ 1 Department of Engineering \\ Metallurgy, University of \\ Johannesburg, South Africa \\ ORCiD® identifiers \\ J.K. Kabasele \\ https://orcid.org/0000-0003-4488-5544 \\ K.D. Nyembwe \\ https://orcid.org/0000-0003-1802-699X}

DOI

http://dx.doi.org/10.7166/32-3-2615

\section{ABSTRACT}

In a post-pandemic world, health and environmental safety will become a more important issue than it was before the COVID-19 pandemic. Several fields of engineering, including the foundry industry, have already adopted health and safety measures in the workplace. The risk of pulmonary disease caused by the inhalation of fine particles of silica sand, the main moulding material used in the foundry industry, is rampant in that industry. In terms of environmental protection, the new regulatory restrictions on the disposal of used sand create the need for moulding aggregates to be more recyclable than silica. Chromite sand is an alternative refractory sand for metal casting applications, and is abundant in South Africa. The present study investigated whether this aggregate has better overall reusability than silica. The focus of this study is on the use of chromite sand in foundries as a contribution to improving health in the workplace and to reducing the environmental impact of foundry sand.

\section{OPSOMMING}

In 'n post-pandemiese wêreld sal gesondheid en omgewingsveiligheid 'n belangriker kwessie word as wat dit voor die COVID-19-pandemie was. Verskeie velde van ingenieurswese, insluitend die gieterybedryf, het reeds gesondheids- en veiligheidsmaatreëls in die werkplek aangeneem. Die risiko van longsiekte wat veroorsaak word deur die inaseming van fyn deeltjies silikasand, die vernaamste gietmateriaal wat in die gieterybedryf gebruik word, is welbekend en dra ernstige gevolge. Wat omgewingsbeskerming betref, skep die nuwe regulatoriese beperkings op die wegdoen van gebruikte sand die behoefte dat gietaggregate meer herwinbaar is as silika. Chromietsand is 'n alternatiewe vuurvaste sand vir metaalgiettoepassings, en is volop in Suid-Afrika. Hierdie studie ondersoek of hierdie aggregaat beter algehele herbruikbaarheid het as silika. Die fokus van hierdie studie is op die gebruik van chromietsand in gieterye as 'n bydrae tot die verbetering van gesondheid in die werkplek en om die omgewingsimpak van gieterysand te verminder.

\section{INTRODUCTION}

Metal casting makes use of either permanent or disposable moulds. The sand casting method falls into the latter category. Silica sand is the preferred moulding aggregate in sand casting, since it is readily available and is cheap world-wide. Foundry silica sand with a size distribution of between 50 and 60 AFS (220 to 250 microns) produces moulds with a good surface finish that requires low binder additions. Foundry-grade silica sand grains are round with a medium to low sphericity, which improves flowability, provides better permeability, and creates a strong mould with the addition of less binder [1].

However, silica dust has been associated with respiratory diseases such as silicosis and tuberculosis. Lung cancer has also been reported in cases of advanced silicosis [2]. Silicosis is dependent on the size of the silica particles. Heavier particles of silica drop rapidly to the floor and are not considered a threat. Lighter particles have a higher probability of being inhaled, since they can float in the air for longer. At a diameter of 100 microns, the particles can be inhaled, but are not small enough to reach the inner regions of the lung. However, once their diameter decreases to 10 microns, the particles can travel to the top areas of 
the lung. At a diameter of five microns and less, silica fines become a real concern, as they are able to migrate to the deepest part of the lungs, causing scarring of pulmonary tissue. Table 1 provides the settling speeds of silica dust in still air, based on particle size [3].

Table 1: Settling rate of silica sand particles in still air [3]

\begin{tabular}{cc} 
Diameter of particle in microns & Time to fall one meter (minutes) \\
\hline 100 & 0.07 \\
5 & 8.20 \\
2 & 47.57 \\
1 & 177.17 \\
0,5 & 613.52 \\
0,25 & 1935.70 \\
\hline
\end{tabular}

The Department of Labour has reported that most South African foundries do not provide accurate or complete measurements of dust in the workplace. According to the survey, less than $30 \%$ of local foundries record actual measurements of dust levels. Furthermore, an uncontrolled dust hazard was found in all foundries surveyed by the National Centre for Occupational Health in South Africa. Since its 2005 report, the Department of Labour has revised its regulations on the amount of silica dust allowed in workplace air from $0.4 \mathrm{mg} / \mathrm{m}^{3}$ to $0.1 \mathrm{mg} / \mathrm{m}^{3}$ [4].

In the context of the global impact of the Covid-19 pandemic, the subject of silicosis and silica-related respiratory diseases has become even more relevant. An investigation was conducted in the United States of America (USA) with a population of 1871 adult patients who had been admitted to hospital to be treated for Covid-19. The report concluded that pre-existing respiratory diseases are a reliable predictor of mortality and of severe disease outcomes in Covid-19 patients. Patients with pre-existing repiratory illnesses had a greater need for mechanical ventilation and admission to an ICU than patients without a pre-existing respiratory illness. In view of what has been discussed so far, It can be concluded that a greater exposure to silica dust could put the workforce at risk of developing more severe case of Covid-19 [5].

The size of foundry silica is affected by the various foundry processes to which the sand is subjected. During the process that the foundry sand undergoes, it is milled, then mixed using a roller mixer, paddle mixer, or vibrating mixer. This mechanical force applies stress to the sand particles. Next, the temperature of the sand mould is raised rapidly to hundreds of degrees centigrade during casting. The thermal shock from the rapid rise in temperature weakens the integrity of the particles. Finally, during sand reclamation, the sand grains are subjected to both thermal and mechanical load. Since mould aggregates are subjected to stresses (thermal and mechanical), it comes as no surprise that the individual grains would break into finer particles [6]. Figure 1 is a comprehensive diagram of all of the stresses acting on the sand grains during a typical sand casting process.

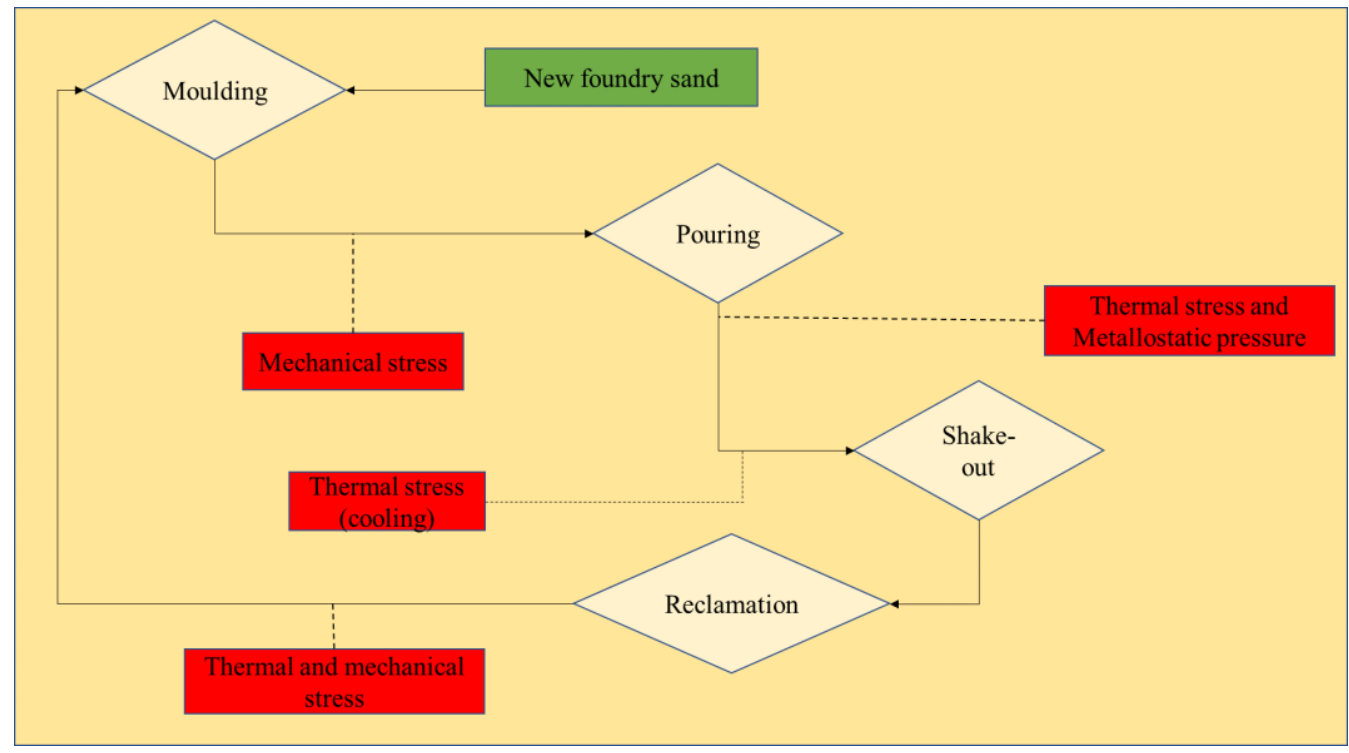

Figure 1: Types of stress acting on sand grains in a typical sand casting process [6] 
The generation of fine particles is a frequent occurrence during the reclamation of sand, since mechanical crushing and heat treatment are part of the process. During the reclamation process, the amount of dust generated is used to measure the efficiency of the reclamation unit or process [7]. Dry reclamation, in particular, produces large quantities of fine particles because pneumatic forces are required to separate bonded sand grains by mechanical attrition. The elimination of fine particles reduces the reusability of the sand and promotes waste. Virgin sand is therefore added to reclaimed sand to improve mould efficiency. A successful reclamation process requires about $10 \%$ to $20 \%$ of new sand [8].

However, reclamation is not as effective as expected. In some instances, up to $50 \%$ new sand is combined with reclaimed sand to make it reusable. Around 25000 and 250000 tons of used foundry chromite sand and silica sand respectively were reported to be dumped each year in South Africa [9]. The shortage of space in South Africa impacts the fees for waste disposal significantly. The tipping fee is about USD34 per ton locally, while in the United Kingdom it is about USD4.3 [10]. This is an alarming statistic, given that there are strong economic incentives to support the reclamation and reuse of foundry sands, as a way both to reduce material costs and to avoid the high expense of waste sand disposal [11]. Sand reclamation has been implemented for several years for the following reasons:

- Increasing costs for disposing of the chemically bonded sand that is used to make moulds and cores. This is generally the case for those sands containing aromatic compounds (phenols, styrene, etc.), which are used once, as opposed to 10 times for greensand.

- Increasing expenditure as a result of higher delivery costs and freight rates.

- $\quad$ Stricter environmental restrictions on the mining of new sands.

- Stricter environmental restrictions on the disposal of solid waste and the availability and cost of using approved landfill sites [11].

The demand for silica sand may change over time, with several regions of the world moving away from using aggregate for the application of sand casting. In the USA, for example, a new silica rule introduced by the US Department of Labour is being implemented to limit exposure to silica dust. This new silica rule requires stricter dust control methods and corresponding training for the workforce [12]. In other regions of the world, such as Wales and Australia, silica has already been completely banned from foundries [13]. It is therefore crucial that an alternative to silica sand, with better recycling yield properties and lower risks to health for the workforce, should be investigated.

In this study, chromite sand has been selected as the suitable alternative to remedy the two main issues raised about the use of silica in foundries. The choice of chromite sand was motivated by the fact that South Africa has the largest deposit of chromite in the world. According to the 2021 United States Geological Survey report, South Africa accounted for more than $40 \%$ of the world's chromite production, followed by Kazakhstan, Turkey, and India, which produce 20\%, 19\%, and $8 \%$ respectively [14]. Furthermore, the sand's foundry properties are superior to those of silica. As a moulding material, chromite sand has low thermal expansion, better heat conductivity, and better refractoriness. It also promotes reduced metal penetration, which eliminates defects such as veining and sand burning, which are typical with silica-based moulds. The material is also used for large casting parts and castings of several high alloy metals, which is either impossible or difficult with silica sand [1] [13]. Most importantly, chromite used in foundry applications is known to be environmentally and health-friendly. According to the Globally Harmonized System of Classification and Labelling of Chemicals and the US Occupational Safety and Health Administration (OSHA), foundry chromite sand is not listed as a physical or chemical hazard, nor as a human health or environmental hazard [15] [16]. The international regulation on the acceptable time weight average exposure to chromite sand dust sets it at $0.5 \mathrm{mg} / \mathrm{m}^{3}$, which is five times higher than the current occupational exposure limit (OEL) for respirable crystalline silica (RCS) for both mining and non-mining industries in South Africa, which has been kept at a value of $0.1 \mathrm{mg} / \mathrm{m}^{3}$ or lower. This only reaffirms the notion that chromite dust is generally more tolerable than silica in ensuring health safety in the foundry industry [15] [17].

Previous investigations into the reusability of foundry silica sand were based on its resistance to crushing [6]. The present investigation will assess the reusability of chromite sand by focusing on the rate of fine particle generation when the sand is subjected to reclamation.

For this study, one sample each of local silica and chromite foundry sand was used. The experiment replicated the application of stress on foundry sand during sand reclamation. Both samples of sand were subjected to an artificial thermal-mechanical load in order to evaluate the rate of fine particle generation. 
This section expands on the experimental procedure of the investigation.

\subsection{Experimental procedure}

The methodology followed the experimental procedure presented in Figure 2.

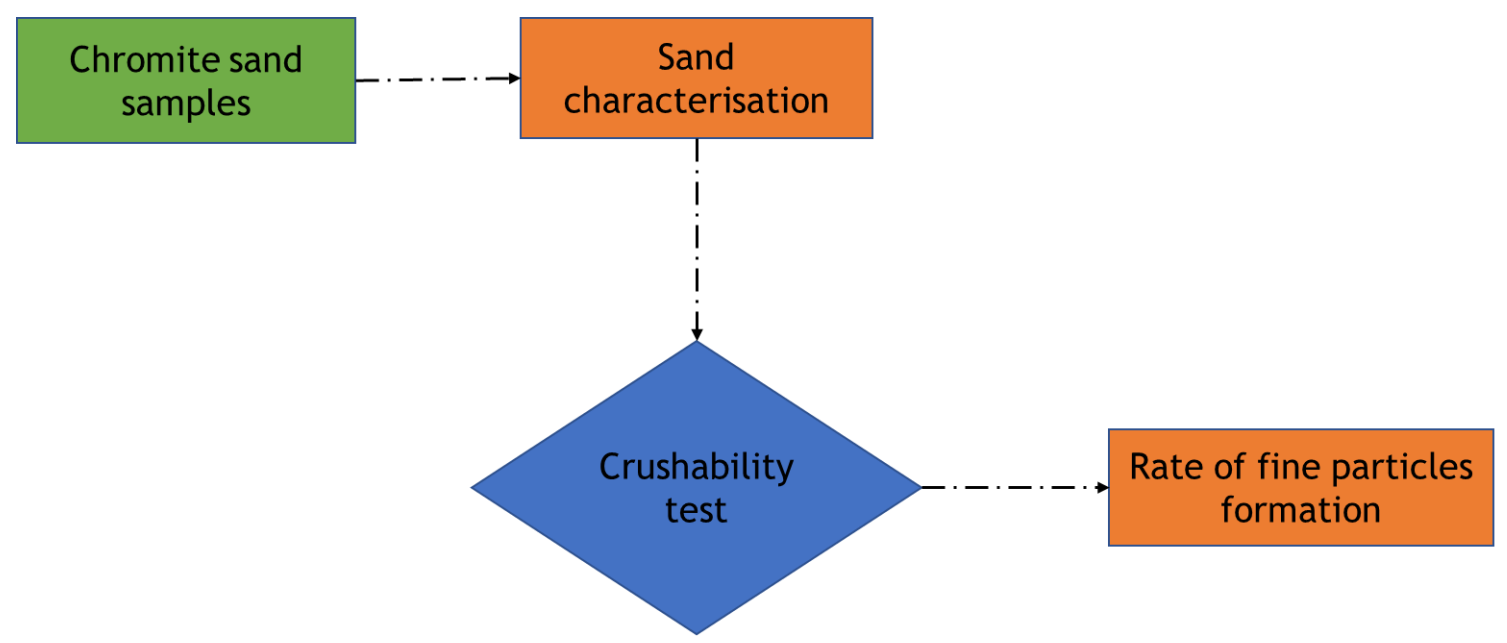

Figure 2: Experimental procedure flow chart

\subsection{Preparation of sample}

The sample size was made of two types of local foundry sands: silica sand and chromite sand. These samples were donated by two local foundry sand suppliers. An amount of $1100 \mathrm{~g}$ of each sample was collected for testing.

\subsection{Sand characterisation}

The following tests were performed on the sand samples:

- chemical analysis

- $\quad$ sieve analysis

- $\quad$ grain morphology analysis

\subsubsection{Equipment used in sand characterisation}

The equipment required to perform the sand characterisation was a scanning electron microscope, an Xray fluorescence unit, and a sieve shaker, as shown in Figure 3.

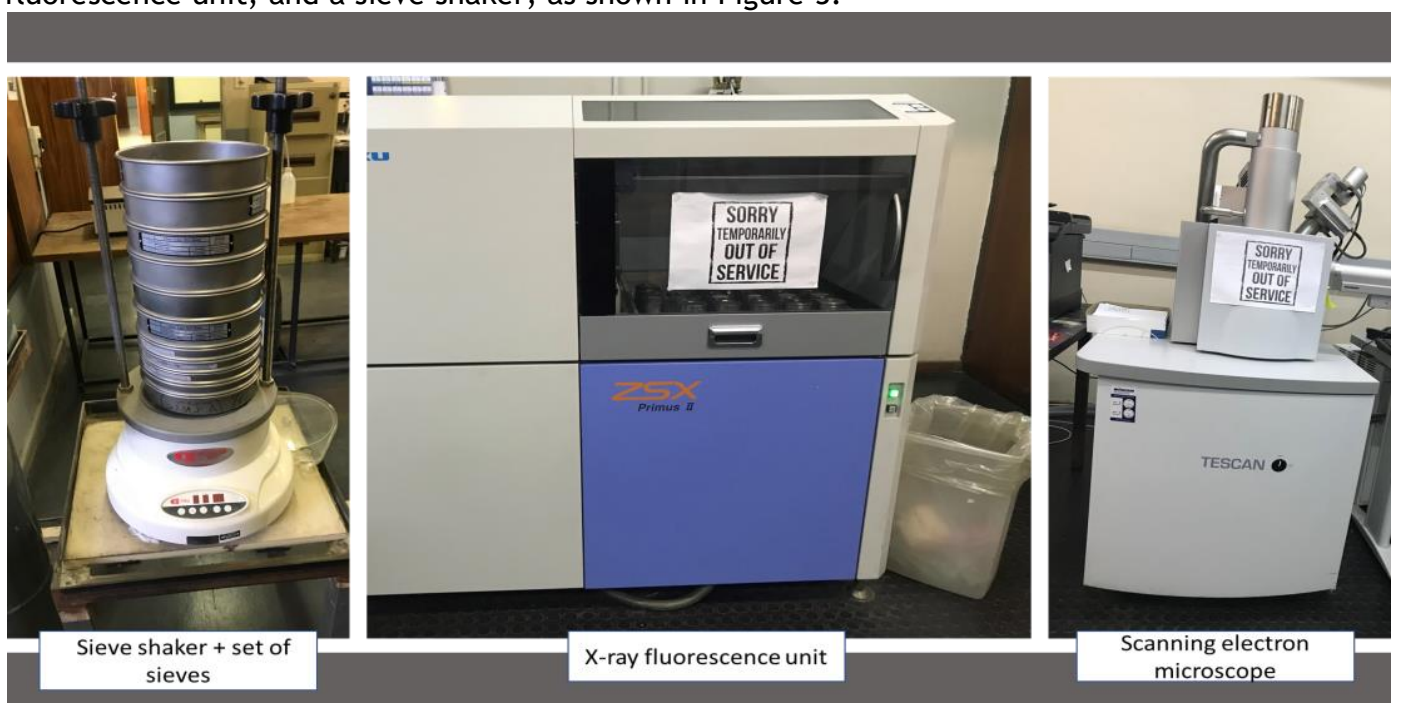

Figure 3: Sand characterisation equipment 


\subsubsection{Procedure used to perform sand characterisation}

The chemical analysis was run through an X-ray fluorescence (XRF) unit. Sieve grading was performed according to the American Foundrymen Standard (AFS 1106-00-S and BCIRA 16-7). The latter test focused on determining the fineness of the grain size, expressed as an AFS number, the size distribution, and the quantity of fine particles. The grain morphology was assessed using a scanning electron microscope.

\subsection{Crushability test}

In this stage, mechanical and thermal stresses were applied artificially to the sand grains.

\subsubsection{Equipment used to perform the crushability test}

Testing the crushability of sand requires a sinter furnace, a rod mill, a scale, and steel rods, as shown in Figure 4.

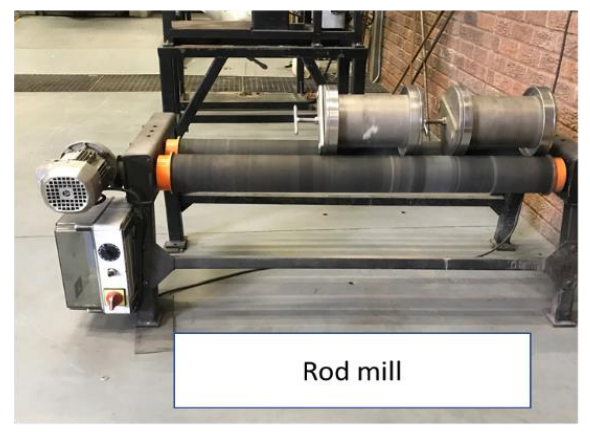

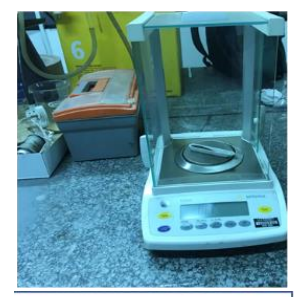

Weight scale
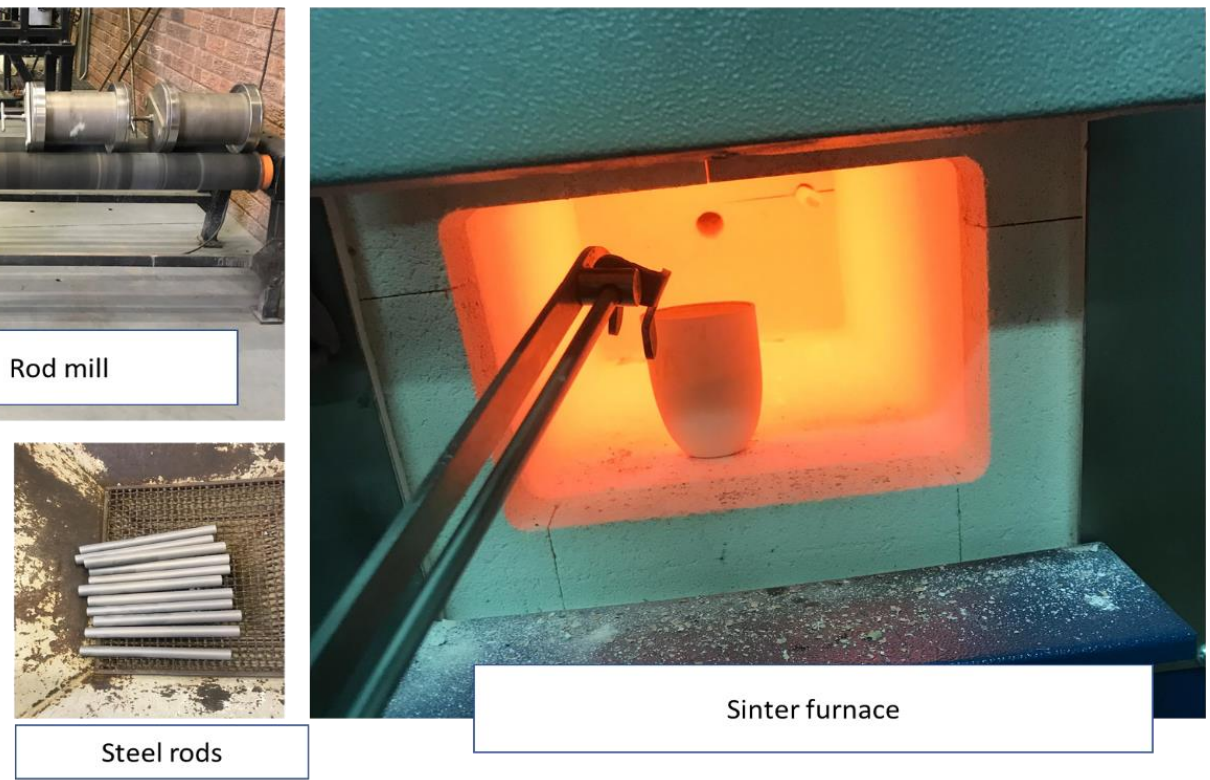

Figure 4: crushing test's equipments

\subsubsection{Procedure used to perform the crushability test}

This test is conducted according to the following steps:

1. Weighing and screening of $100 \mathrm{~g}$ sand sample through a set of screens arranged according to the AFS standard AFS 1106-00-S.

2. Recording the weight of fine particles. The particles with a size of 75 microns and below are considered fines.

3. Rod milling of the sand. The milling process was performed for 3 minutes.

4. Heat treatment in a sinter furnace of the milled sample. The operating temperature was $700^{\circ} \mathrm{C}$

5. Cooling of the sand to room temperature.

6. Repeat of the heat treatment and cooling cycle 10 times.

7. Finally, the sample was screened and the final amount of particles was recorded.

8. The test was repeated with the milling time increased to 6 and $9 \mathrm{~min}$.

\subsection{Determination of the rate of fine particles generation}

The rate of fine particle formation was the ratio between the amount of fine particles after stress application over the original amount of fines in the sand. the rate of fine particle generation is expressed as a function of the milling time in minute.

This section compiles the results obtained after the experiment has been conducted. 


\subsection{Characterisation}

Test results related to the sand characterisation are shown in Table 2. Chromite sand has a coarser aggregate with an AFS number of 49.22. On the other hand, silica sand has more fine content. The grain morphology reveals important information about both samples. Chromite has an irregular shape with several cleavage planes while silica sand is a mix of grains with irregular shapes and rougher surfaces, and grains with smoother surfaces.

Table 2: Characterisation results

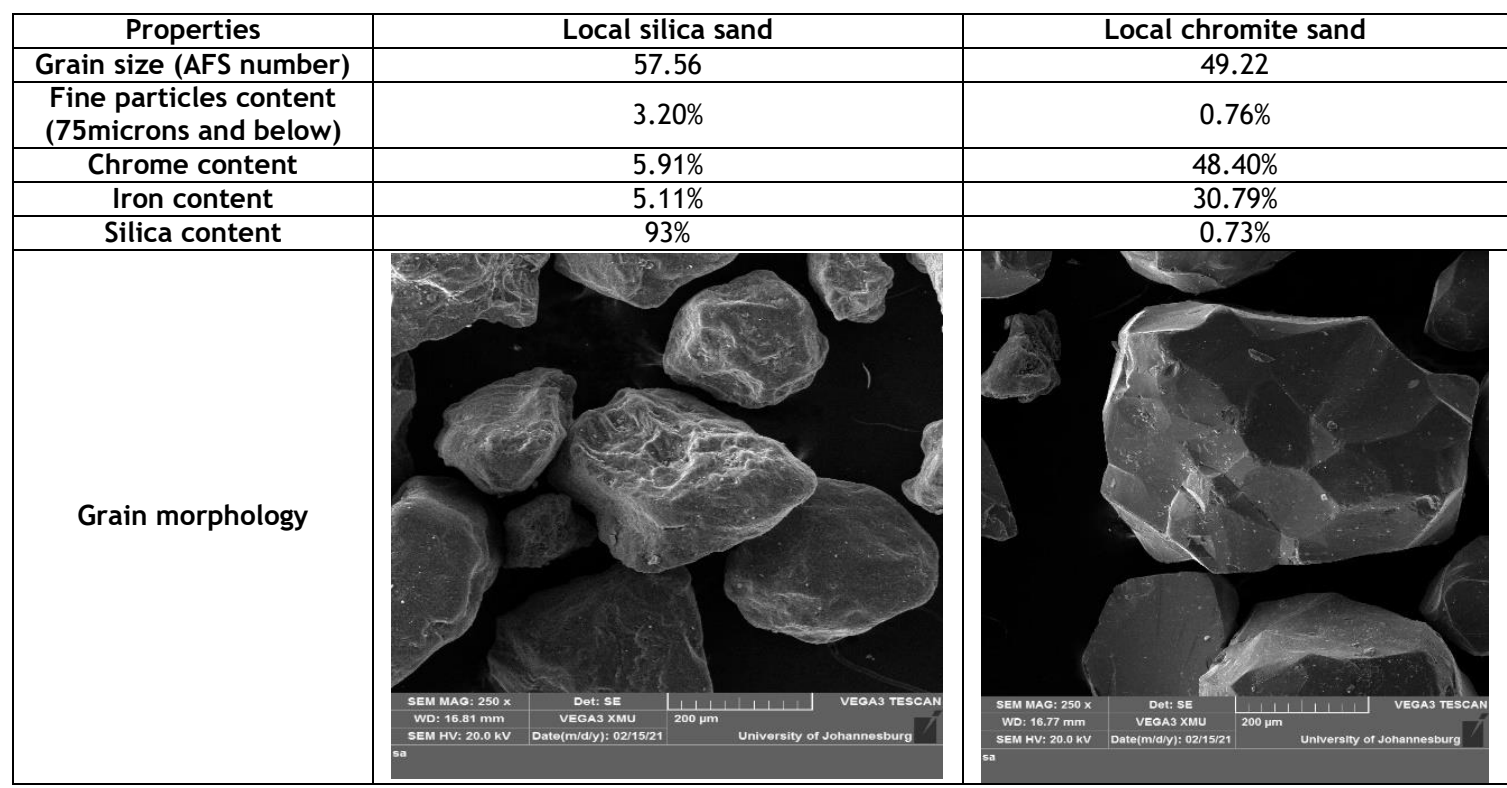

According to Figure 5, both types of sand present a normal size distribution. The grains are distributed across several sieve sizes which ensures excellent mould packing and resistance to thermal shock.

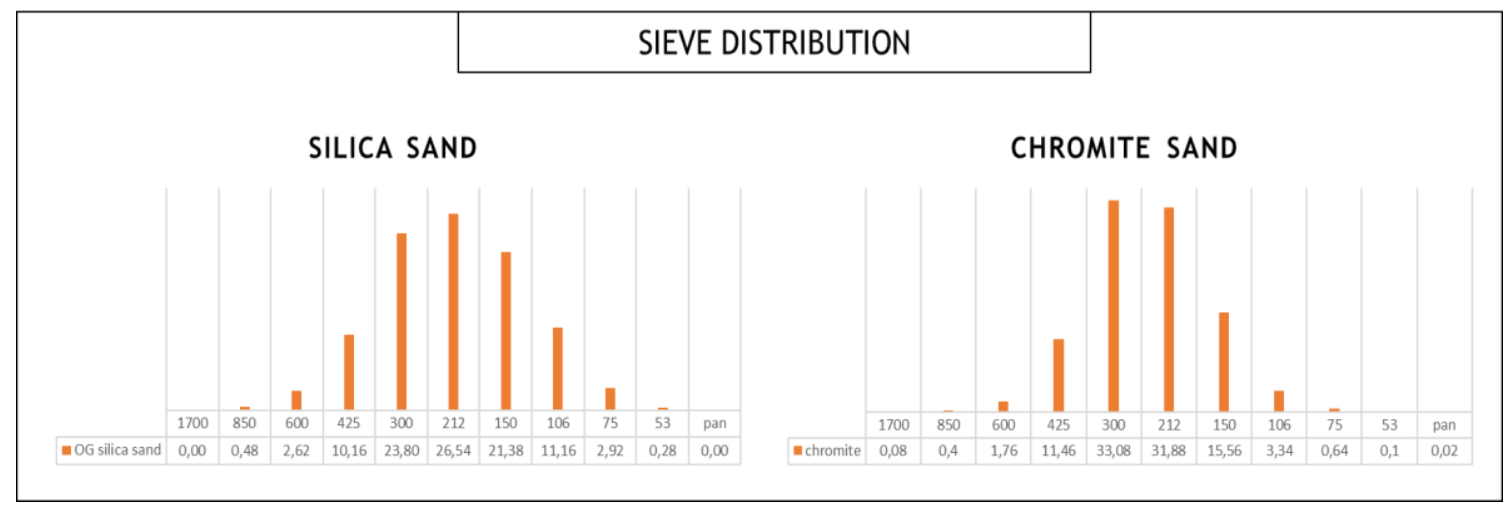

Figure 5: Sieve distribution

\subsection{Correlation between crushing test and sand characterisation}

The integrity of the grains was overcomed by thermal and mechanical stress. According to Figure 6, the grains have decreased in size. However, the observation is not sufficient to determine whether chromite is the superior aggregates in terms of reusability. 


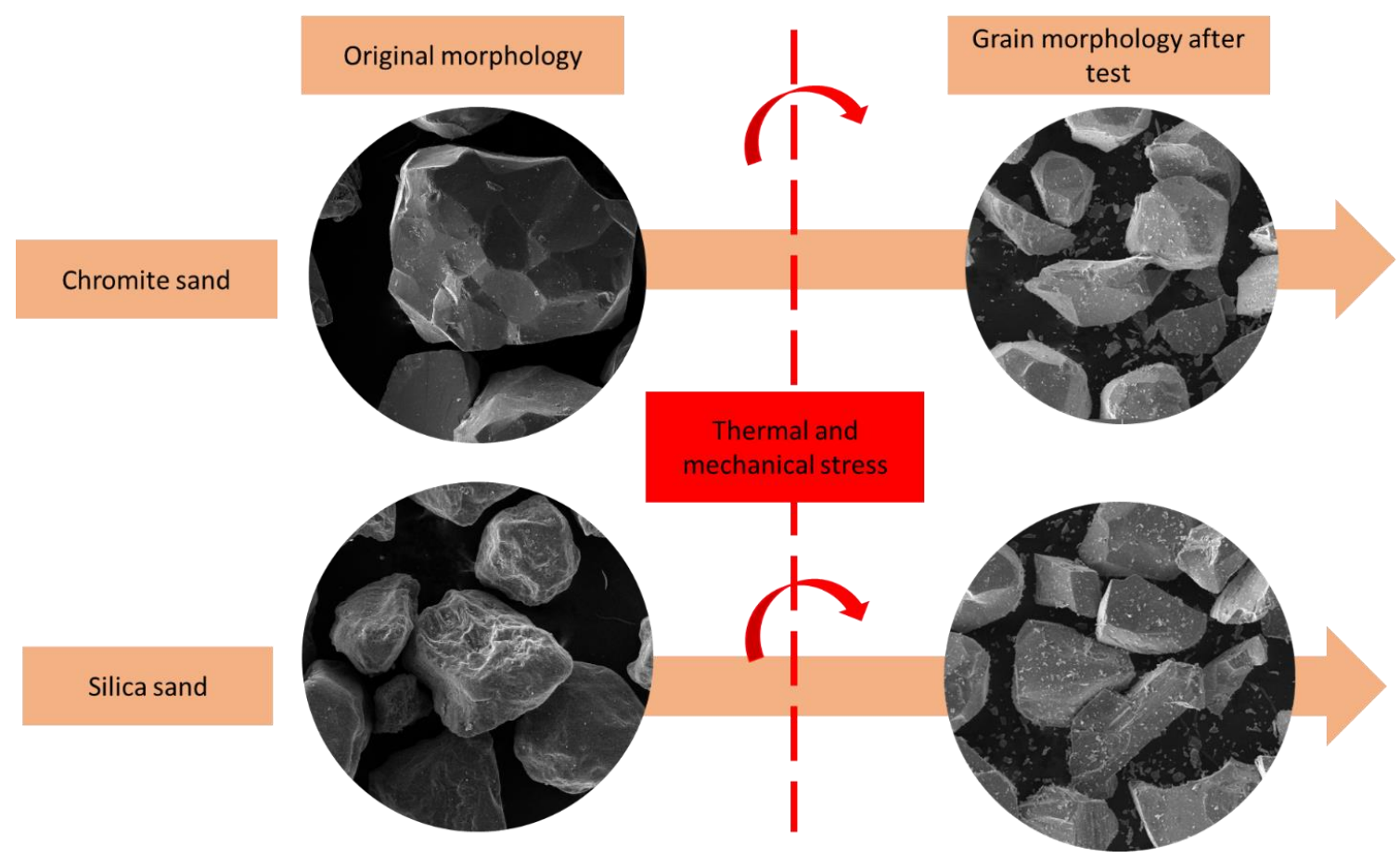

Figure 6: Change in grain morphology after application of thermal and mechanical stress

The size distribution of both samples was altered by the stress application, as shown in Figure 7. The size distribution of silica sand was affected to a greater extent than that of chromite sand, and deviated more from the the standard AFS number for foundry grade sand, which ranges between 40 and 60 .

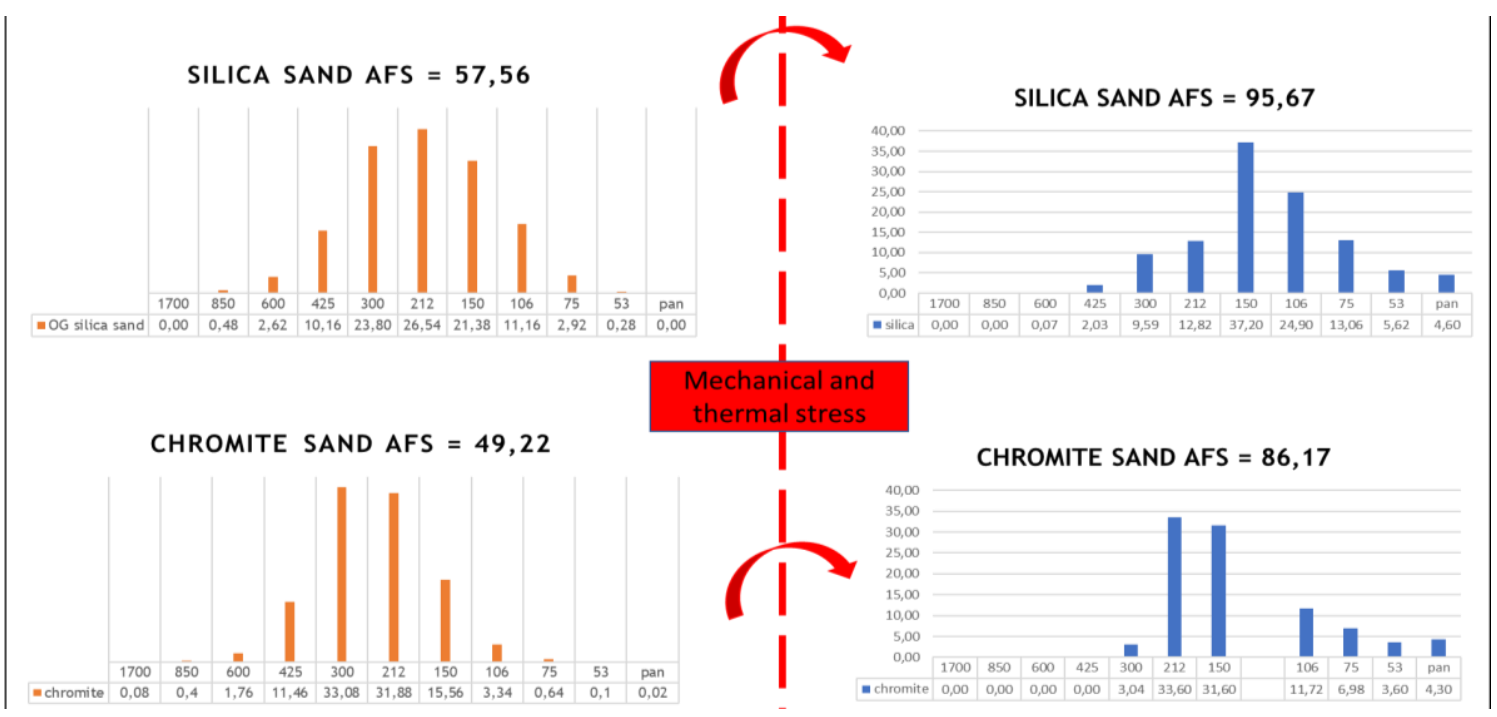

Figure 7: Changes in grain size distribution after application of thermal and mechanical stress

\subsection{Rate of fine particles increase}

Figure 8 shows the results obtained after the application of thermal and mechanical stress. 


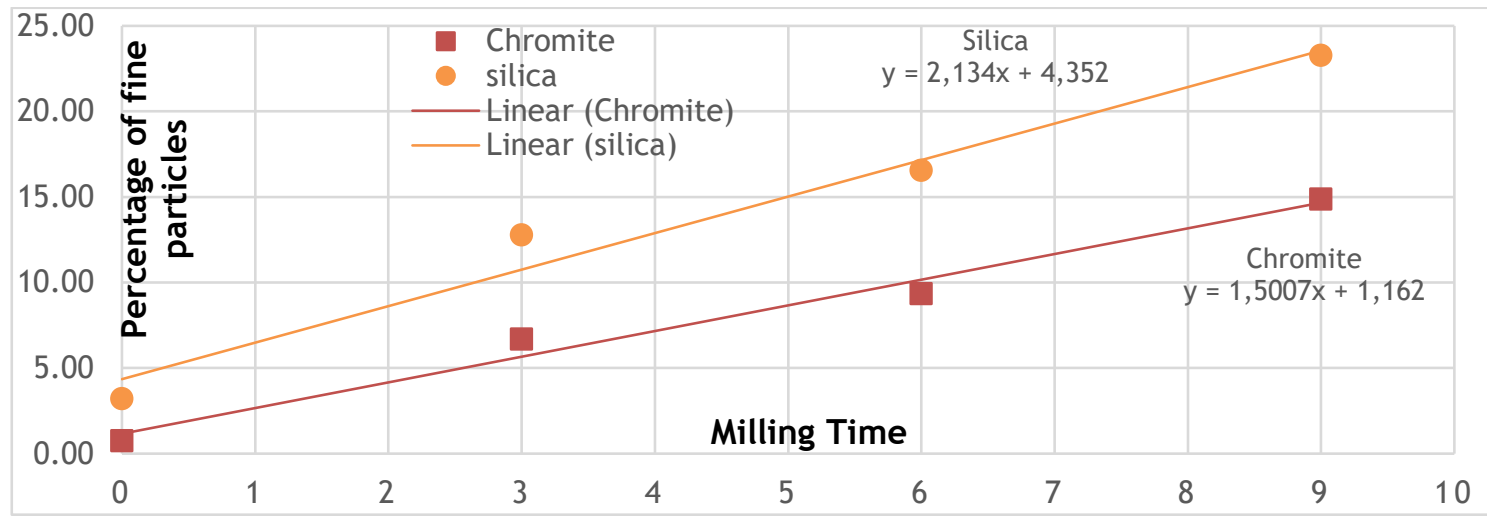

Figure 8: Linear expression of increase in fine particles

The numerical value of the rate of fine particle formation is derived from the linear expression in Figure 8. According to Figure 9, silica generates fine particles at a faster rate than chromite sand.

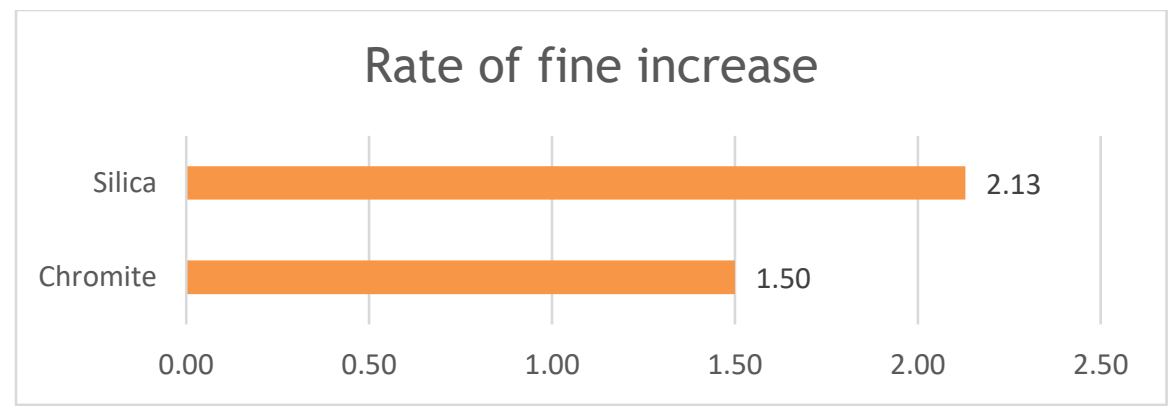

Figure 9: Rate of fine particle increase

\section{DISCUSSION OF RESULTS}

Coarser ceramic grains accommodate higher concentrations of flaws and depression, which makes them prone to breaking [18]. Under thermal and mechanical stress application, silica sand generates fines at a faster rate than chromite sand, despite the former material starting with a finer size distribution than the latter. This is a peculiar outcome, since the sand characterisation established silica sand as having finer grains on average than chromite.

The coefficient of the thermal expansion of silica could be a reason behind silica's poor resistance to crushing. The failure of ceramic material is dependent on the severity of the thermal expansion [19]. The driving force behind thermal expansion is phase transformation. In the case of silica, the aggregate transforms from alpha to beta quartz. The sudden change in crystal configuration creates internal strains on cooling [20]. Thus rapid heat transfer and rapid cooling are the reason for the thermal shock that takes place in silica particles [21]. As shown in Figure 10, silica sand has a greater likelihood of experiencing thermal shock than chromite by virtue of its higher coefficient of thermal expansion. 


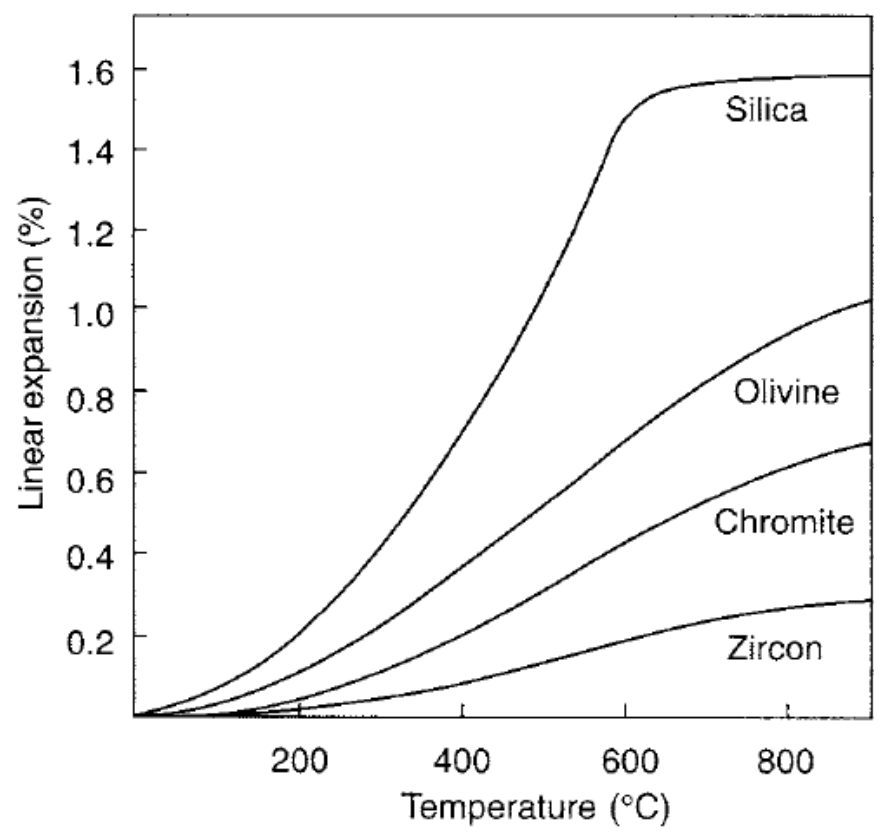

Figure 10: Foundry sand's coefficient of linear expansion

Chromite sand is rich in alumina spinel phase such as chromite and magnesiochromite. The compound is a stable refractory material at higher temperatures, as shown in Table 3 [22]. For this reason, chromite has a better resistance to stress than silica sand.

Table 3: Melting of spinel [23]

\begin{tabular}{|c|c|c|c|}
\hline Spinel & Molecular mass & Melting point & Calculated melting point \\
\hline MgO.Al2O3 & 30,58 & 2105 & 643,7 \\
\hline MgO.Cr2O3 & 25,89 & 2400 & 621,0 \\
\hline FeO.Cr2O3 & 36,26 & 2160 & 783,0 \\
\hline FeO.Fe2O3 & 7,27 & 1600 & 116,3 \\
\hline
\end{tabular}

\section{CONCLUSION}

This study showed that chromite sand could be regarded as a 'green' raw material in the foundry industry because it generates fewer fines, thus requiring less new sand to be added to the system sand; and, because of the lower quantity of fines, it should not cause health problems. This is an especially important factor in enabling the foundry industry to meet the United Nations' sustainable goals in the context of the Covid19 pandemic and beyond. In line with countries such as the USA, South Africa could also introduce regulatory prescriptions to limit the use of silica sand in local foundries.

\section{REFERENCES}

[1] J. Brown, Foseco non-ferrous foundryman's handbook, Oxford ,Butterworth-Heinemann, 1999.

[2] C. Güngen, Y. Aydemir, H. Çoban, H. Düzenli and C. Tasdemir, "Lung cancer in patients diagnosed with silicosis should be investigated," Respiratory Medicine Case Reports, vol. 18, pp. 93-95, 2016.

[3] R. C. Scholz, T. J. Slavin and K. Rowntree, Control of silica exposure in foundries, Schaumburg, Illinois, American Foundry Society, 2007. [Online]. Available: https://afsinc.s3.amazonaws.com/Documents/EHS/silica_book_no\%20copyright.pdf . [Accessed 15 November 2021].

[4] Department of Labour, South Africa, "National programme for the elimination of silicosis," Pretoria, Department of Labour,2005. [Online].Available: https://www.ilo.org/wcmsp5/groups/public/---ed_protect/---protrav/--safework/documents/policy/wcms_118112.pdf. [Accessed 15 November 2021].

[5] P. Lohia, K. Sreeram, P. Nguyen, A. Choudhary, S. Khicher and H. Yarandi, "Preexisting respiratory diseases and clinical outcomes in COVID-19: A multihospital cohort study on predominantly African American population," Respiratory Research, vol. 32, no. 1, pp. 1 -9, 2021.

[6] Y. Dai, Q.-Y. Ma, X.-H. Li, X. Zhang, F.-P. Hu, Y. Zhang and W.-D. Xie, "The research on characterization of crushability for foundry sand particles,” Archives of Foundry Engineering, vol. 17, no. 4, pp. 231-235, 2017. 
[7] R. Dańko, J. Dańko and M. Holtzer, “Foundry sand reclamation-theory and industrial practice," Proceedings of 69th World Foundry Congress, pp. 623-631, October 2010.

[8] M. C. Ashton, England Patent 4685973, 1985. [Online]. Available: https://patents.google.com/patent/US4685973A/en. [Accessed 15 November 2021].

[9] J. Nyembwe, M. Makhata, F. Banganayi and K. Nyembwe, "Characterization of foundry waste sand streams for recycling applications in construction industry," Waste and biomass valorization, vol. 9, no. 9, pp. 1681-1686, 2018.

[10] P. Iloh, G. Fanourakis and A. Ogra, "Evaluation of Physical and Chemical Properties of South African Waste Foundry Sand (WFS) for Concrete Use," Sustainability, vol. 11, no. 1, pp. 1-29, 2019.

[11] F. Nabhani, M. Mckie and S. Hodgson, "A case study on a sustainable alternative to the landfill disposal of spent foundry sand," Sustainable Manufacturing, vol. 3, no. 1, pp. 1-19, 2013.

[12] United States Department of Labor, “OSHA's proposed crystalline silica rule: Overview," Occupational Safety and Health Administration, United States Department of Labor, August 2013. [Online]. Available: https://www.osha.gov/silica/factsheets/OSHA_FS-3683_Silica_Overview.html [Accessed 21 June 2021].

[13] J. Campbell, Complete casting handbook, 2nd ed., Oxford, Butterworth-Heinemann, 2015.

[14] US Geological Survey, “United States Government survey: Mineral commodity summaries," 1 February 2021. [Online]. Available: https://s3-us-west-2.amazonaws.com/prd-wret/assets/palladium/production/mineralpubs/mcs/mcs2015.pdf [Accessed 13 February 2021].

[15] Adriatik Advanced Materials, Safety data sheet: Chromite Sand, Palm Beach, Adriatik Resources Limited, 2019. [online]. [Online]. Available: https://img1.wsimg.com/blobby/go/905ddd9d-8f3b-4a33-b8ca14f289cc4520/downloads/US\%3ASDS.pdf?ver=1585357495461. [Accessed 21 June 2021].

[16] LKAB, Non-hazardous material safety data sheet for chrome sand, Flixborough, LKAB Minerals, 2019.

[17] D. H. Brouwer and D. Rees, "Can the South African milestones for reducing exposure to respirable crystalline silica and silicosis be achieved and reliably monitored?", Frontiers in Public Health, vol. 8, pp. 107-119, 2020.

[18] R. Brook, Concise Encyclopedia of Advanced Ceramic Materials, Stuttgart, Elsevier, 1991.

[19] S. J. Bennett, “An absolute interferometric dilatometer,” Journal of Physics E: Scientific Instruments, vol. 10, no. 5, p. 525-530, 1977.

[20] A. Fahmy and A. N. Ragai, "Thermal expansion behaviour of two phases solid," Applied Physics, vol. 41, no. 13, pp. 5108-5111, 1970.

[21] R. W. Davidge, "Thermal shock," in Concise Encyclopedia of Advanced Ceramic Materials, R. J. Brook, Ed., Stuttgart, Elsevier, 1991, pp. 478-481.

[22] E. J. W. Verwey and E. L. Heilmann, "Physical properties and cation arrangement of oxides with spinel structures: I. Cation arrangement in spinels," Journal of Chemical Physics, vol. 15, no. 4, pp. 174-181, 1947.

[23] N. McEwan, T. Courtney, R. A. Parry and P. Knupfer, "Chromite - A cost-effective refractory raw material for refractories in various metallurgical applications," Southern African Pyrometallurgy 2011 International Conference, Johannesburg, 2011. 